
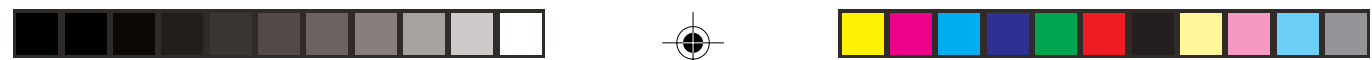

Articles

\title{
6. Media ownership in the Pacific: Inherited colonial commercial model but remarkably diverse
}

\begin{abstract}
This article describes the historic conditions governing newspaper and media ownership in the Pacific. It argues that historically there have been three kinds of media in the Pacific: Mission or church-owned or directed, governmen- owned or directed and commercial. The missions and churches were responsible for the first newspapers aimed exclusively at indigenous populations and in Papua New Guinea have continued to play a key role in the media. The commercial press could only exist when there was a sufficient population to support it and so it tended to appear in those countries with the largest expatriate populations first. The continued dominance of the commercial media by Western companies in the largest islands has been largely due to the cost of producing these commodities. Locally-owned commercial media have been on a much smaller scale, but they have nonetheless had an impact. The national or government-owned or directed media were generally inherited from the departing metropolitan powers and represent a much diluted version of the public service model. While the article argues that the dominance of the commercial press in such markets as PNG, Fiji and New Caledonia by Murdoch and DassaultHersant is probably commercially inevitable, it also argues that the media scene in the Pacific is actually remarkably diverse.
\end{abstract}

PHILIP CASS

Zayed University, Abu Dhabi

82 PACIFIC JOURNALISM REVIEW 10 (2) 2004 
I

$\mathrm{N}$ BROAD terms, the Pacific media have been owned and operated through the private sector, the state sector and the church. Privately-owned media are generally descended from newspapers which were established during the colonial period to serve the needs of expatriate populations. These have survived the transition to independence and remain in the hands of outside interests. For the most part state-owned media emerged when the governments of the newly created island nations inherited media established by the departing colonial administrations. These were usually radio stations, but sometimes, as in the Solomon Islands, they included newspapers. Missionary or church-owned media have generally been limited to a particular congregation or language group. Such media usually takes the form of small newspapers. However, there have been exceptions, most notably in Papua New Guinea where Word Publishing has had a major influence on the media through Wantok Niuspepa and the now defunct Times of PNG/Weekend Independent (Cass, 2000/2001a; PMW 3722 PNG).

However, the categories of private, state and church are not all embracing, since they concern the modern news media and ignore traditional methods of communication through oratory and the creation of cultural artefacts. Such categories also ignore adopted cultural industries such as book publishing, music recording and film making. I might suggest that for an illiterate PNG villager, hearing somebody singing 'PNG yu mas kamap wan nesen' on the radio is more likely to generate national consciousness than 20 solemn exhortations in the editorial columns of the Post-Courier.

The Pacific media are not homogeneous. They range from tiny, A4 sized publications to glossy monthly magazines such as Islands Business and from tiny radio stations run by fundamentalist Christians to pan-Pacific operations that link FM radio stations in Suva and Port Moresby.

Each media organisation is a product of the particular set of circumstances that led to the creation of each island state. What is true of one country is not true of another. In the Pacific, each country is an exception; indeed, it would be better to speak of 'media in the Pacific', rather than 'Pacific media'.

Some generalisations nevertheless can be made: The churches have played a significant role in developing grassroots media and in creating written forms of indigenous languages, although it is doubtful whether anything like Word Publishing could have arisen in a country as sectarian as Fiji.

One could also generalise that where there was a sufficiently large expatriate population there could be found a privately-owned, commercial 

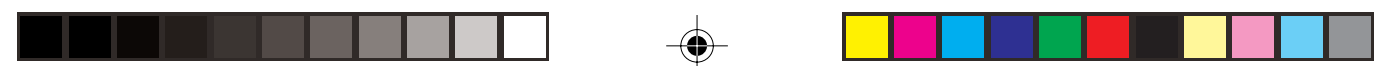

\section{MEDIA OWNERSHIP AND DEMOCRACY}

newspaper. However, one would then have to offer the caveat that New Caledonia did not have a commercial newspaper until the 1970s.

One could argue that the two major media centres in the Pacific, Papua New Guinea and Fiji, have similar kinds of media, with News Corporation owning the leading national dailies of both countries. However, as Robie (2003) has shown, journalists in these countries have quite divergent attitudes towards the role of the media.

If we are to consider the current status of media in the Pacific, then we must investigate three questions: The economic context of media production, the nature of the audience which consumes media products, and whether that audience is adequately served by media outlets.

\section{The economic context of media production in the Pacific}

\section{Papua New Guinea}

Media organisations in the Pacific are a business, just as they are anywhere else. Regardless of whether revenue is generated by advertising, or an allocation from a government ministry, or from a plate handed round during a missionary's home leave, the media need money to stay alive. The two oldest - and largest - Pacific dailies, the PNG Post-Courier and The Fiji Times, operated in countries with the largest expatriate populations. Consequently these newspapers attracted sizeable investment. Murdoch owns the PostCourier and The Fiji Times because he might, one day, make some money from them; in the meantime he can keep other competitors at bay. It is doubtful if Nai Lalakai or Shanti Dut make one iota of difference to the profits of News Ltd, but so long as he owns them, Murdoch knows that he has a stake in the market. A tiny Hindi weekly that gives away glossy A4 posters of Lord Ram or Sunil Shetty is a strategic, not a commercial, asset (Shawcross, 1992; Coleridge, 1998). Even the shade of the Rabaul Times, which ceased publication in 1959, can be detected in the footnotes of News Ltd's annual reports. As late as 1998, Murdoch owned a ghost just in case anybody else wanted to open a newspaper in the ruins of the volcano town (Newscorp, 1998: 60).

This was exactly the same reasoning that led the Hersant group to invest in La Depêche de Tahiti and La Nouvelle Caledoniènne. Strategic considerations were behind the opening of the Malaysian-owned National in Port Moresby. At this time Malaysian timber interests were active in PNG and 
Malaysian companies were supplanting established firms such as Steamships, Burns Philp, Carpenters and Morris Hedstrom (Robie, 1993, 1995).

The major international players are in the Pacific to keep the opposition out, as much as anything else. If News Ltd abandoned PNG or Fiji then Fairfax or Consolidated Press would step in. Because the major dailies are owned by large, multinational companies, they can afford to sustain losses that would cripple their smaller rivals. With multinational investment backing, they can afford to print in colour, have the best computers and offer competitive salaries. This situation will remain unchanged short of the press being nationalised or governments introducing tough legislation to reduce the level of foreign ownership. ${ }^{1}$

The economic costs of distribution effectively confine daily newspapers to the major towns. Where population is concentrated on an island with good roads and distribution, this is less of a concern, but some newspapers face quite large obstacles. Consider the case of the Eastern Star, whose circulation area covers the entire Milne Bay province in PNG. The paper comes out fortnightly, but readers in the outlying islands receive their copy only when a trawler or workboat gets out to them. Sometimes three months' worth of papers turn up at once. Other problems faced by publishers in the smaller island states include the cost of newsprint and equipment and the difficulty of obtaining reliable technical support for computers and presses.

Loney (2002:134) proposes desktop publishing as a solution, but this only seems possible if we are talking about an owner-operator publication with a fixed and reliable advertiser-customer base. Publishers of any kind are often faced with prohibitive taxes and duties. Crowl (1996) notes that in Samoa at that time the duty on newsprint was 20 per cent, with a 60 per cent levy on plates, film and ink. Other, more practical, difficulties intervene. I remember watching a group of dedicated parish workers in PNG's Enga province trying to print an A4 newsletter on a laser printer and being held up for two days by power cuts. It would have been easier to use a hand-cranked Gestetner.

Government-owned media must rely on a mix of advertising and direct subsidy to survive. As the economies of the newly created island states collapsed in the 1990s, there was less money available for media organisations. This meant that in the smaller states, radio facilities acquired from the departing British or Australians or New Zealanders, almost ceased to function. This was particularly true of the colonial administered stations taken over by 

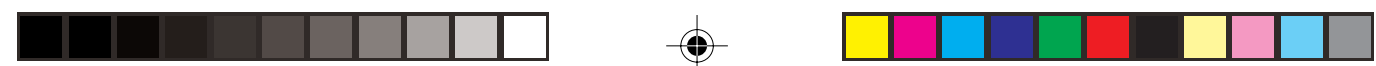

\section{MEDIA OWNERSHIP AND DEMOCRACY}

the new PNG Government (as opposed to the ABC). Elsewhere in the Pacific, stories abound of stations using and re-using the same scraps of tape because they have nothing else left. The solutions are often as unpalatable as the problem (Centurion, 1994).

What emerges, then, is a picture of great financial inequality. The smaller island states simply do not have the resources to provide public broadcasting; small newspapers with uncertain distribution survive on tiny advertising revenues. Only the main commercial dailies have enough resources to do their job properly. The difficulties faced by media organisations in the region reflect widely varying levels of literacy, population size and gross domestic product. The combination of these factors is amply demonstrated by an examination of the newspaper market in PNG and Fiji, the two major South Pacific markets outside Australia and New Zealand.

Newspapers in Papua New Guinea have always experienced low circulations. This was the case among the expatriate population before independence in 1975 and among the indigenous English-literate elite and the small expatriate population afterwards. Although PNG has the largest population in the Pacific, its literacy rate of 66 per cent and a per capita GDP of \$US2200, puts it in the bottom third and bottom quarter of Pacific countries of these two categories respectively (see Table 1). Ownership of radios and television sets and the number of internet users as a proportion of the population ranks in the bottom half of Pacific countries (Table 2). With hundreds of local languages, English, Tok Pisin and Motu remain the only truly widespread languages (the latter is confined to Papua and English to the educated elite). Both daily newspapers are printed in English and both have large circulations only in Port Moresby and the larger towns such as Lae and Rabaul.

Both dailies are foreign-owned, the Post-Courier by News Ltd and The National by a combination of local shareholders and Rimbunan Hijau, a Malaysian logging company. The Post-Courier is the longest surviving newspaper in PNG, having been formed from a merger of the South Pacific Post and the Rabaul Times Courier in 1969. The latter was itself the result of a merger between the Rabaul Times and the Lae-based New Guinea Courier a decade earlier (Cass, 2004).

Ownership of the Post-Courier passed from the Melbourne-based Herald and Weekly Times Ltd to News Ltd, making it part of the Murdoch chain in Oceania. The South Pacific Post dated back to the 1950s, but the Courier could 

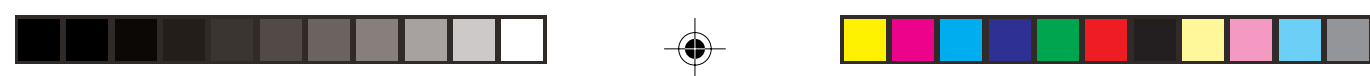

MEDIA OWNERSHIP AND DEMOCRACY

\begin{tabular}{|c|c|c|c|c|c|}
\hline \multicolumn{6}{|c|}{ Rank ordering for: } \\
\hline \multicolumn{2}{|c|}{ Literacy (total pop.) } & \multicolumn{2}{|l|}{ Population } & \multicolumn{2}{|c|}{ GDP (US dollars) } \\
\hline 1 Samoa & $99.7 \%$ & 1 PNG & $5.4 \mathrm{~m}$ & $1 \mathrm{NZ} /$ Aotearoa & $\$ 21,600$ \\
\hline $2 \mathrm{NZ} /$ Aotearoa & $99 \%$ & $2 \mathrm{NZ} /$ Aotearc & $3.9 \mathrm{~m}$ & 2 Guam & $\$ 21,000$ \\
\hline - Guam 99\% & & $3 \mathrm{Fiji}$ & 880,874 & 3 Fr. Polynesia & $\$ 17,500$ \\
\hline 4 Tonga & $98.5 \%$ & 4 Solomon Is & 523,617 & 4 New Cal./ & \\
\hline 5 Fr.Polynesia & $98 \%$ & 5 Fr. Polynes & 266,339 & Kanaky & $\$ 15,000$ \\
\hline 6 Am. Samoa & $97 \%$ & 6 New Cal. / & & 5 Nthn Mariana & is $\$ 12,500$ \\
\hline - Nthn Marianas & s $97 \%$ & Kanaky & 213,629 & 6 Palau/Belau & $\$ 9000$ \\
\hline 8 Cook Islands & $95 \%$ & 7 Vanuatu & 202,609 & 7 Am. Samoa & $\$ 8000$ \\
\hline - Niue & $95 \%$ & 8 Samoa & 177,714 & 8 Fiji & $\$ 5800$ \\
\hline $10 \mathrm{Fiji}$ & $93.7 \%$ & 9 Guam & 166,090 & 9 Samoa & $\$ 5600$ \\
\hline - Marshall Is. & $93.7 \%$ & 10 Tonga & 110,237 & 10 Cook Islands & s $\$ 5000$ \\
\hline 12 Palau/Belau & $92 \%$ & 11 FSM & 108,155 & - Nauru & $\$ 5000$ \\
\hline 13 New Cal./ & & 12 Kiribati & 100,798 & 12 Wallis/Futun & 1a $\$ 3700$ \\
\hline Kanaky & $91 \%$ & 13 Nthn Mar & as 78,257 & 13 Niue & $\$ 3600$ \\
\hline 14 FSM & $89 \%$ & 14 Am. Sam & 57,902 & 14 Vanuatu & $\$ 2900$ \\
\hline 15 PNG & $66 \%$ & 15 Marshall & 57,738 & 15 Tonga & $\$ 2200$ \\
\hline 16 Vanuatu & $53 \%$ & 16 Cook Isla & 21,200 & - PNG & $\$ 2200$ \\
\hline 17 Wallis \& Fut & una $50 \%$ & 17 Palau/Bel & 20,016 & 17 FSM & $\$ 2000$ \\
\hline 18 Kiribati & No data & 18 Wallis/Fu & a 15,880 & 18 Solomon Is. & $\$ 1700$ \\
\hline - Nauru & No data & 19 Nauru & 12,809 & 19 Marshall Is. & $\$ 1600$ \\
\hline - Solomon Is. & No data & 20 Tuvalu & 11,468 & 20 Tuvalu & $\$ 1100$ \\
\hline - Tokelau & No data & 21 Niue & 2156 & 21 Tokelau & $\$ 1000$ \\
\hline - Tuvalu & No data & 22 Tokelau & 1405 & 22 Kiribati & $\$ 800$ \\
\hline
\end{tabular}

Source: Figures in this table are derived from The CIA World Factbook 2004.

www.odci.gov/cia/publications/factbook

Full data referred to in this article is posted at the edition's contents page on the Pacific Journalism Review website:www.pjreview.info

trace its roots to the early 1920s when it was set up to cater for the Australians moving in to take over the recently expropriated German plantations. Niugini Nius, which was owned by Talair proprietor Dennis Buchanan, attempted to offer a less Port Moresby-oriented approach to news. Printed in Lae, it faced unrelenting commercial pressure from the Post-Courier and even with a daily circulation of 15,000 eventually closed in 1990. Buchanan was reported to have had trouble obtaining work permits for his expatriate staff.

The National continues to appear in Port Moresby, offering a product which complements the Post-Courier. With its full colour presses, splashy layout and overseas features, it offers a contrast to the Murdoch publication's more staid approach to the news. Australian Audit Bureau of Circulations figures for 2001 show The National selling 21,036 copies Monday to Friday 

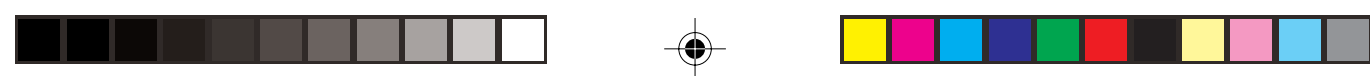

MEDIA OWNERSHIP AND DEMOCRACY

\begin{tabular}{|c|c|c|c|c|}
\hline \multicolumn{5}{|l|}{ Rank ordering for: } \\
\hline TV sets per head & \multicolumn{2}{|c|}{ Radio sets per head } & \multicolumn{2}{|c|}{ Internet subscribers per head } \\
\hline $1 \mathrm{NZ} /$ Aotearoa & 1 Guam & $1: 0.75$ & $1 \mathrm{NZ} /$ Aotearoa & $1: 1.2$ \\
\hline 2 New Cal/Kanaky & $2 \mathrm{NZ} /$ Aotearoa & $1: 1$ & 2 Guam & $1: 3.3$ \\
\hline 3 Palau/Belau & 3 American Sar & toa 1.1 & $3 \mathrm{New} \mathrm{Cal} / \mathrm{Kanak}$ & $k y: 1: 7$ \\
\hline 4 American Samoa $1: 1.4$ & 4 Samoa & 1:1.01 & 4 Cook Islands & $1: 7.5$ \\
\hline 5 Guam & 5 Tokelau: & $1: 1.4$ & 5 French Polynes & sia $1: 7.6$ \\
\hline 6 Cook Islands & 6 Cook Islands & $1: 1.5$ & 6 Tuvalu & $1: 8$ \\
\hline 7 French Polynesia & $7 \mathrm{Fiji}$ & 1:1.6 & 7 Fiji & $1: 17.6$ \\
\hline 8 Fiji & 8 Palau/Belau & 1:1.6 & 8 Wallis \& Futun & a $1: 17.6$ \\
\hline 9 Tuvalu & 9 Kiribati & $1: 1.6$ & 9 FSM & $1: 18$ \\
\hline 10 Samoa & 10 French Poly & esia 1:2 & 10 Vanuatu & $1: 28.9$ \\
\hline $11 \mathrm{FSM}$ & $11 \mathrm{New} \mathrm{Cal} / \mathrm{Kar}$ & aky $1: 2$ & 11 Tonga & $1: 38$ \\
\hline 12 Tonga & 12 Niue & 1.2 & 12 Samoa & $1: 44.4$ \\
\hline 13 Vanuatu & 14 Tuvalu & $1: 2.8$ & 13 Marshall Islan & nds $1: 44.4$ \\
\hline 14 PNG & 14 Vanuatu & $1: 3$ & 14 Nauru & $1: 49$ \\
\hline 15 Kiribati & 15 Solomon Isle & nds 1:9 & 15 Kiribati & $1: 50.3$ \\
\hline 16 Solomon Islands $1: 174$ & 16 PNG & $1: 13$ & 16 PNG & $1: 72$ \\
\hline 17 Niue $\quad$ No data & 17 FSM & $1: 11.5$ & 17 Solomon Islan & inds $1: 238$ \\
\hline 18 Nthn Marianas No data & 18 Nthn Marian & is No data & 18 Nthn Marianas & as No data \\
\hline - Marshall Is. No data & - Marshall Islan & Is No data & - Niue $\quad N$ & No data \\
\hline - Nauru & - Nauru & No data & - American Samo & oa No data \\
\hline - Tokelau No data & - Tonga & No data & - Palau/Belau & No data \\
\hline - Wallis \& Futuna No data & - Wallis and Fut & una No data & - Tokelau & No data \\
\hline
\end{tabular}

Source: Figures in this table are derived from The CIA World Factbook 2004.

www.odci.gov/cia/publications/factbook

Full data referred to in this article is posted at the edition's contents page on the Pacific Journalism Review website: www.pjreview.info

against 25,044 for the same period for the Post-Courier (www.business.vu.edu.au/bho2250/Top20Media/TopMediaPacific.htm). Critics have complained that The National is unlikely to publish stories critical of the exploitation of PNG's timber resources being conducted by its Malaysian owners, or of Government members who obtained shares in the company. Indeed, in January 2004, the editor of The National was defending his newspaper from accusations that it favoured the Government (PMW 4277 PNG, 2004).

The only locally-owned English national newspaper was The Times of $P N G$, later renamed The Weekend Independent (and eventually The Independent). A sister publication to Wantok, it provided solid investigative journalism under its editor, Anna Solomon, a range of feature articles drawn from alternative news sources and overseas newspapers and incisive reporting on

88 PACIFIC JOURNALISM REVIEW 10 (2) 2004 

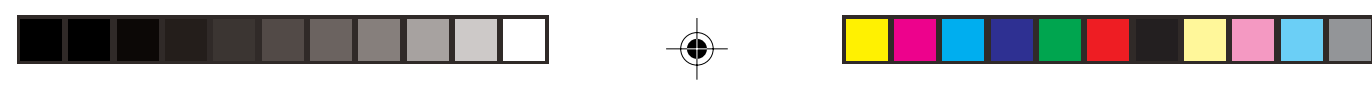

\section{MEDIA OWNERSHIP AND DEMOCRACY}

local politics. Tragically, it did not survive for long into the new century (PMW 3722 PNG, 2002).

Readers outside Port Moresby are served erratically by a variety of churchbased and provincial government news sheets and publications. With the almost complete collapse of regional radio services in many provinces, there is an opportunity for small scale newspapers to meet the needs of communities deprived of news, but this has not been taken up. Attempts to start regional newspapers in other areas have not been very successful. The short-lived Highlands Post, which appeared in Mt Hagen in the early 1980s, appeared to be intended primarily as a promotion for its printing press owners. There have been various publications in Rabaul, but the destruction of the town in the 1994 eruption has effectively ended publication there. The Arawa Bulletin on Bougainville was closed by the outbreak of the civil war (Layton, 1992).

Other regional publications have included the Madang Watcher, originally set up by former Prime Minister Michael Somare's daughter Bertha as an end-of-term project for her journalism course at the Divine Word Institute (now University) in Madang. The paper relied heavily on the patronage of local parliamentarian Sir Peter Barter.

The electronic media in Papua New Guinea are a glaring example of poorly distributed resources. Although there is a television channel, EMTV, many parts of the country no longer have local radio services. There is little prospect of them being restored because the equipment is so old it would have to be replaced, rather than repaired (Centurion 1994). However, the low literacy rate means that, where available, radio remains a vital source of information, especially for villagers (www.freemedia.at/wpfr/Australasia/ wpf_aust.htm).

\section{Fiji}

A study of the other major Pacific market shows a completely different story. With a population of 880,874 , Fiji boasts a literacy rate of 93.7 per cent. Its per capita GDP of \$US5800 ranks just outside the top third of Pacific nations (Table 1). Fiji is in the top third of Pacific countries in terms of internet usage (Table 2).

It also has the longest and most complicated media history of all the island nations. There is one indigenous language, English, as a lingua franca among Europeans and educated Fijians and Indo-Fijians and Fijian Hindi dominates 

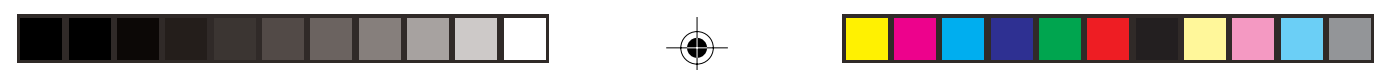

\section{MEDIA OWNERSHIP AND DEMOCRACY}

among the latter. The circumstances provided a coherent and literate market for media organisations. Whereas the commercial press in PNG is almost entirely a post-Second World War creation, the commercial press in Fiji can be traced back to 1869 . Outside New Zealand it is Fiji, with publications in its three main languages, multilingual radio services, magazines aimed at a transPacific market and commercial radio networks that reach into PNG, that constitutes the centre of Pacific journalism.

The first commercial newspaper in Fiji was The Fijian Weekly News and Planters' Journal, published in Levuka in 1868, followed a year later by The Fiji Times, which remains the dominant newspaper in Fiji. During the colonial period, the English language press was largely the voice of the planter and capitalist. ${ }^{2}$ A number of English language newspapers came and went during this period. These included The Western Pacific Herald (1901-18; when it was incorporated into The Times), The Fiji Argus (1874-84), The Fiji Colonist and Levuka Gazette (1897-1900), The Observer (1876-1883), The Pacific Age (1921-23) and The Polynesian Gazette (1884-1943).

The Times remained largely unchallenged until after the Second World War when three new papers appeared. These were The Guardian (1947), which became The Weekly Guardian and The Oceania Daily News (1948). These papers were set up by political rivals of The Times' manager, Alport Baker. The Oceania Daily News was a more advanced newspaper than The Times, printing overseas news from United Press alongside sports and racing pages from New Zealand. The Oceania Daily News began to publish a weekly page of Fijian news and, eventually translated overseas news into Fijian. This took readers away from The Times. At this time this was the only nongovernment source of news for the Fijians. ${ }^{3}$

The biggest challenge for The Fiji Times came in 1974, with the opening of the Fiji Sun and the Sunday Sun. According to a Ministry of Information publication, the Sun was selling 20,608 on weekdays, compared to 19,600 Richstad records for The Times. The Sunday Sun claimed to be selling about 18,000 copies an edition in 1974, against 21,000 copies for The Fiji Times Saturday edition. The Hongkong and New Zealand-owned Sun and the Sunday Sun were both closed after the 1987 coups when the military regime imposed strict censorship. The Sun refused to republish under censorship. The new Fiji Sun (no direct descendant of the pre-1987 coups paper) appeared late in 1999 and has struggled with the Daily Post for second place in the market. The 

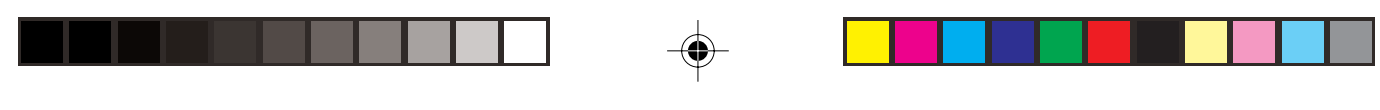

MEDIA OWNERSHIP AND DEMOCRACY

revived Sun was backed by Fijian Holdings, C. J. Patel and Vinod Patel Ltd, with Ba Provincial Council also taking an interest. Australian Audit Bureau of Circulations figures for 2001 show The Fiji Times selling 27,124 copies in the Monday to Friday market, the Daily Post selling 12,000 and the Sun selling 10,000 (www.business.vu.edu.au/bho2250/Top20Media/ TopMediaPacific.htm).

\section{The Fijian press}

It was only in the 1950s that a serious effort was made to provide a Fijian language newspaper. Yadra Viti first appeared in 1946 and was really the first independent newspaper for Fijians. However, it lasted only a few issues and was not revived until 1955 when it claimed to be the first paper owned and managed by a Fijian who owned his own printing press. Griffen (1991) credits Yadra Viti with having the same political objectives as the European and Indian press; that is, to promote the political interests of Fijians as a race.

In the meantime, three other Fijian language publications had emerged. These were Duisiga, Volagauna and Vakalelewa Ni Pasifika. Duisiga appeared in 1951 and lasted a year until it went bankrupt. Volagauna was financed by the publisher of Duisiga, G. N. Dean, and was supported by the Government which released staff to work on it. By 1973, Volagauna was claiming a weekly circulation of 12,500.

The Fiji Guardian (1954-57) was intended to be a multiracial publication but its content was still aimed largely at expatriates. It was published by G. N. Dean in collaboration with Frank Ryan, who had been sacked as editor of The Fiji Times. The Fiji Guardian's major innovation was the translation of news and opinion from the Indian and Fijian language press. This was the first time an English language publication had attempted to expose its readers to the views of other communities. Another attempt at a bilingual newspaper was the Fiji Nation/Na Tovata, published by the Alliance Party. It was printed half in English and half in Fijian. A paper with a clearly political stance, it was published by The Fiji Times twice a week.

Nai Lalakai, which survives today, was started in 1962. Published by The Fiji Times, it was claiming a circulation of close to 10,000 by its 10 th year of publication, more than its Hindi stablemate Shanti Dut.

The Indo-Fijian press

The Indian language press in Fiji has had a difficult history. There have been PACIFIC JOURNALISM REVIEW 10 (2) 200491 

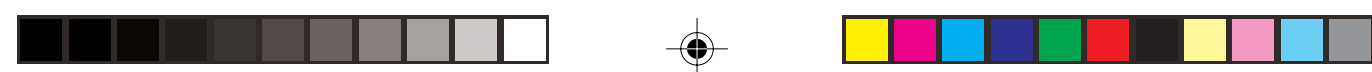

\section{MEDIA OWNERSHIP AND DEMOCRACY}

a great variety of publications, produced in several Indian languages with different religions and political purposes. The Indian press was more politically motivated than any other and reflected a continuing concern with events in India and political developments there. Because of this, it was generally regarded as subversive by the British colonial Government.

The first independent newspaper for Indian Fijians was the Indian Settler, which appeared in 1917. It was edited by Dr Manilal, after Fijian Indians had asked Mahatma Gandhi, who was then in South Africa, to send somebody to Fiji to work for Indian rights. The paper was published in English, Hindi and Urdu and agitated for an end to the indenture system, but collapsed after a few months for lack of funds.

The next Indian paper to be published was Raj Dut, a Government paper which appeared in 1922 and lasted until 1930. Edited by a Methodist missionary, it did not have a wide circulation. The first significant newspaper for Indians in Fiji was Fiji Samachar, which first appeared in 1923. It was political in tone, and represented the views of the Hindu reformist movement, the Arya Samaj Society. Fiji Samachar was the longest surviving of the independent Indian newspapers and was still being published when Richstad, McMillan and Barney made their pioneering survey of the Pacific press in 1973.

Shanti Dut, which is published by The Fiji Times, grew out of the collapse of Vriddhi in 1930, which had been produced by Dr Hamilton Beattie, a European doctor sympathetic to Indian political aims. Vriddhi's editor, G. D. Sharma, approached the Times with the idea of publishing a vernacular newspaper. It was originally a bilingual publication, with two pages in English and the rest in Hindi. The only other significant Indo-Fijian paper was Jai Viti, which first appeared in February 1959, surviving until the mid-1970s with a weekly circulation of nearly 8000 .

Attempts to meet the combined demands of the English, Fijian and Hindispeaking markets in the press have proved unsustainable. The needs of each market have been met when the media have treated Fiji's population as separate. Lifebuoy laundry soap can be sold just as easily in three languages as one. Fijians have taken to the electronic market with alacrity. There is one television set for every 10 Fijians and two radio sets for every three Fijians. Fiji is in the top third of internet usage, with one out of every 17 Fijians being a registered internet user (Table 2).

Why has Fiji provided a more diverse media environment than Papua New

92 PACIFIC JOURNALISM REVIEW 10 (2) 2004 

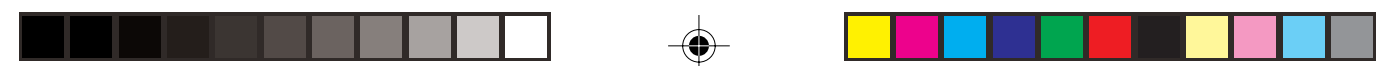

MEDIA OWNERSHIP AND DEMOCRACY

Guinea? Part of the answer is, obviously that Fiji's per capita GDP is nearly three times as great as PNG's, but does the audience itself supply an answer? (Table 1).

\section{The Pacific media audience}

The 'fatal impact' fallacy

It is unfortunate that many who criticise the Pacific media assume that Pacific Islanders form a helpless and passive audience at the mercy of an overwhelming and uncomprehended media assault. It is as if the Frankfurt school had been reborn again under a coconut tree.

A study of the available statistics shows that at last half the population of the region is highly literate, has ready access to radio, less easy access to television broadcasts (but probably much easier access to video). Pacific Island readers are beginning to use the internet and, at least in the main centres, enjoy reasonable access to newspapers and magazines in their own language. Many islanders have close links with a metropolis (New Zealand for Polynesia, France for the French territories, the US for Micronesia and Australia for Melanesia) through migration, education and work. In short, they have adapted to Western-style media technology and products on their own terms, just as their ancestors did to 19th century technology in the period of European colonisation.

However, the 19th century colonisation informs many critiques of the interaction between Pacific audiences and the media. I refer here to the school of 'fatal impact' historical studies that grew up after the publication of Alan Moorehead's book of the same name (1966). While an important work, the fatal impact thesis assumed that once the all-powerful Europeans arrived, the noble, but doomed, Islanders, succumbed to smallpox and gin. This general view was challenged in the 1970s and 1980s with the arrival of Islandscentered history, which argued that the local populations were adaptable enough and smart enough to recover from the arrival of the Europeans and to confront the new world on their own terms.

Unfortunately, many people (including what we might call media anthropologists) cling to the notion that the poor defenceless Islander will immediately succumb to anything inflicted by the wicked West. Thus, all too many critics of the Pacific media presume that only the noble Western academic, $\mathrm{PhD}$ in one hand, Baudrillard or Foucault in the other (replacing the volume 

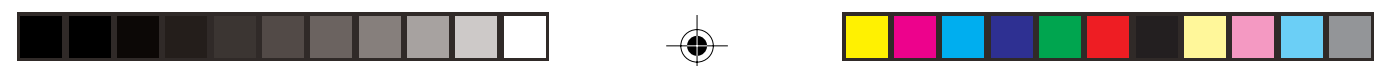

\section{MEDIA OWNERSHIP AND DEMOCRACY}

of Rousseau of an earlier age) can tell the Islander what is wrong. Without such academic analysis, the poor (but still noble) viewer of Fiji One or reader of the Post-Courier will have their culture and traditions destroyed by a combination of Rupert Murdoch and re-runs of TVNZ's Shortland Street. ${ }^{4}$

Such views ignore the fact that most Pacific media are locally owned, and that traditional forms of oral communication continue to supplement and correct what is known from the modern media outlets. Traditional societies are more adaptable and resilient than many outsiders believe - or want - them to be.

This cultural resilience is probably best exemplified by the fact that written media in indigenous languages have developed separately from the commercial media. The first printing presses in the Islands were established by Christian missionaries and the first Islander proto-journalists had their work published in small, crankily printed mission newspapers. It was the missions which worked in the local languages, not the colonial governments or businesses. Given that the colonial press was almost exclusively aimed at the expatriate market, there was very little reason for local people to buy The Fiji Times or the South Pacific Post.

\section{The missionary press}

Since there can be no newspapers without an audience to read them, it was first necessary to create written versions of local languages and then to teach the Islanders to read the missionary versions of their own languages.

It is crucial to realise that the first newspapers in the Pacific were produced for the Islanders and not the small expatriate communities. The work of the missionaries in transliterating local languages had a profound and lasting impact on literacy and the creation of national identities through language as well as creating opportunities for local writers to express themselves in print.

Today there are still many church publications in the Pacific, printed in a variety of languages. They still have a very small circulation and most are concerned exclusively with parochial matters. English is used either alongside an indigenous language (as in Samoan), or alongside one of the linguae franca of Melanesia. Despite their limited circulations, church newspapers are still important because of their role in preserving local languages and because of their historical function as the home of the Pacific's first indigenous journalists and printers.

The mainstream churches have had their most visible effect in Papua New 94 PACIFIC JOURNALISM REVIEW 10 (2) 2004 
Guinea, where Word Publishing has produced the Tok Pisin weekly Wantok Niuspepa since 1970. I have argued elsewhere that the appearance of Wantok was as much a result of it having an available audience as anything else. Plans for a Tok Pisin weekly in PNG go back to the early 1960s, but it is doubtful whether such a newspaper would have survived before a sufficiently large, Tok Pisin-literate audience existed (Cass, 2001a).

The formation of such an audience directly resulted from the decision by the Divine Word (SVD) missionaries to switch from Tok Ples to Tok Pisin as a lotu language in the 1920s. By working with the rapidly spreading lingua franca, the SVDs were not bound by one particular Tok Ples and thus could communicate more widely (Tschauder, 1992).

The SVD's decision was difficult to make and completely at odds with the policy of most other missions. Most missionaries worked in the local languages because they had to live and work among the people, far more than the plantation owners or colonial officials. Mission language policy and the speed with which they began to produce newspapers was governed by necessity as much as by linguistic theory.

The first printing press in the Pacific was established in Tahiti in 1816 by the London Missionary Society (LMS) and run by William Ellis. Thereafter, the press appeared everywhere the missioner landed (Lingenfelter, 1967 passim). The next printing press was established in Hawai'i in 1821 by Hiram Bingham of the American Board of Commissioners for Foreign Missions. Methodist missionaries brought the first printing press to the Kingdom of Tonga in 1831, their first production being a four-page spelling book. The next mission press was established in the Cook Islands in 1834. The first printing press in Fiji was brought into the country by the Methodists and the book was printed at Lakeba in 1839. In that same year a press was established in Apia in Samoa. A press was established in the Wallis Islands in 1844. In 1848, the LMS and Presbyterian missionaries arrived in the New Hebrides (Vanuatu) with a press. Anglican missionaries established a press in the Loyalty Islands in 1852 and in 1854, Marist missionaries arrived in New Caledonia with the first lithographic press in the Pacific. The first book was printed in Ponape in 1858. The Foreign Missions of Boston were in the Carolines in 1856, bringing with them a small hand press with which they produced a sheet of prayers and hymns. In 1860 they had expanded their activities to the Marshalls where they printed a 44-page primer.

Missionary presses were established in German New Guinea by the PACIFIC JOURNALISM REVIEW 10 (2) 200495 

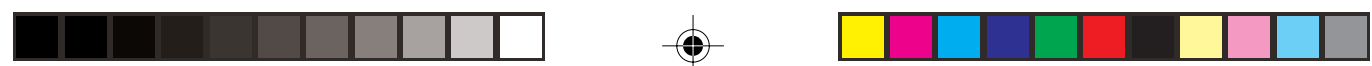

\section{MEDIA OWNERSHIP AND DEMOCRACY}

Lutherans at Finschafen, the Divine Word missionaries at Tumleo and later Alexishafen and by the Methodists and Sacred Heart missionaries in Rabaul. The first missionary newspaper was Jaeng Ngajam, published in Jabem by the Lutherans in 1905, followed by the Methodists' Kuanua A Nilai Ra Davot in 1909. The Marists established the first press in the Solomons at Rua Sura in 1910 (O'Reilly and Laracy, 1972).

Although the importance of the missionary press as a pioneering enterprise cannot be overstated, it was nonetheless eventually overshadowed by the establishment of the commercial press in the islands. No newspaper can exist without the means of production or a common written language of communication, but a commercial press also needs a commercial environment that can guarantee its continued existence.

If churches no longer dominate the media aimed at the Islander population, then their work in translating and codifying local languages endures. Questions of language and literacy continue to affect the media.

\section{Literacy}

More than half the Pacific Island countries claim higher than 90 per cent literacy. Indeed, Samoa claims a higher literacy rate than New Zealand/ Aotearoa. With the exception of Fiji and New Caledonia/Kanaky, the countries with the highest literacy rates are in Polynesia or Micronesia. These countries also have correspondingly high per capita GDPs (Table 1). There appears to be no universal correspondence with population numbers. Literacy rates appear to be low in countries with the greatest linguistic diversity, as in Melanesia.

\section{Radio}

Radio ownership is fairly standard for all Pacific Islands, with most countries having more than one radio for every two or three people, at least enough for one per family. In Guam there are more radios than Guamanians (Table 2). Radio - and radio in the local language or lingua franca - would appear to remain the dominant medium for receiving outside news.

\section{Language}

While English is still fairly dominant, it is often used in tandem with one or even two other languages in some newspapers. Polynesia and Micronesia more commonly adopt a bilingual approach to publication (Layton, 1992). This 96 PACIFIC JOURNALISM REVIEW 10 (2) 2004 
means that English can be used as a lingua franca without marginalising the identity of the local language. However, if language is one of the main tools of self-identification then it can also be divisive. The use of multiple languages may mean that a newspaper such as the English/French/Bislama Vanuatu Hebdomadaire will not carry exactly the same version of the same story in all languages. Sometimes this appears to occur for political reasons, at other times because one language takes up more space than another and so contains less information. Bilingualism can sometimes take the form of separate editions of the same newsapaper. For instance, the Samoa Observer is available in separate English and Samoan editions, while the fortnightly Savali has separate Samoan and English editions.The weekly Le Samoa is believed to print 3000 copies in Samoan and 500 in English (www.tifq.ulaval.ca/axl/ pacifique/samoa.htm).

\section{The internet}

English and French will continue to be used by the elite, especially in television and on the internet. There are plenty of chatrooms for the expatriate Islander population, be they in Tongan or Tok Pisin, but the main languages of the net are English or French. Internet usage in the Pacific is not uniform and contains some surprises. In Tuvalu, every eighth member of the population is a registered user, a figure not much lower than that for French Polynesia where the rate is 1:7.6, or roughly two registered users for every 15 people (Table 2). Closer examination may show that internet usage is for mail, chatrooms and exchanging personal information rather than to search for news or general information. Sites such as Kava Bowl (www.pacificforum.com/kavabowl/) and Wantoks Forum (www.niugini.com/ wwwboard/index.html) serve as alternatives to the mainstream media (Robie, 2001: 268). One may doubt the effectiveness of the internet as a formal, organised agent of social and political change, but it certainly has the potential to influence informal and family communication.

Research in Asia (Inoguchi, 2001) has demonstrated variable political opinions among internet users which may be reflected in attitudes towards the reliability and trustworthiness of governments. A study of internet and email users' attitudes in the Pacific may show similar trends. Latin America offers examples of communal groups such as the Zapatistas using the internet for political ends and promoting radical political alternatives (Peruzzotti and 

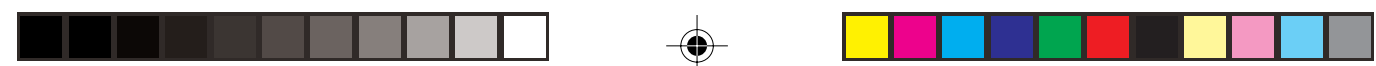

\section{MEDIA OWNERSHIP AND DEMOCRACY}

Smulovitz, 2002). Research in the Pacific may reveal similar examples. In both cases it is the communal, informal and individual users who show the most active awareness of the net's possibilities. What is also apparent is the way in which the net mimics oral communication and informal family discussions along with criticisms of political events. ${ }^{5}$

\section{Television}

Television usage appears to be highest in those islands which have a large expatriate population, such as French civil servants or American soldiers. High television usage also occurs in countries with close ties to New Zealand through migration. Television is almost invariably in English or French, with some content in local languages or linguae franca. The amount of purely local language material is small. Television services will continue to run large amounts of imported material, but many of the places shown in soap operas and news bulletins will actually be familiar to viewers because of family ties. The other problem confronting those who want to make local language programmes is that effective programme exchanges can only be made between French and English. To reach a country outside its country of origin means a programme cannot be in a local language.

\section{Is the Pacific being served adequately by its media?}

Finally we have to ask whether the various audiences in the Pacific are being adequately served by the media. While the 'big' newspapers in the Pacific are owned by expatriates, the majority of newspapers are actually locally owned, edited and managed by islands' nationals (Layton, 1992). The 'big' newspapers are aimed mostly at the national elite and expatriate readers and may have less impact on the 'average' reader than is commonly imagined.

Outside the two largest markets, Papua New Guinea and Fiji, the Pacific offers a picture that is complex and diverse. The Pacific states derive from a mixture of colonial traditions, laws and media practice. Post-independence journalists may have been raised under American-style constitutional guarantees of freedom of speech or under wholly different laws, derived, in the French territories, from the Code Napoleon and European Union legislation. They might have learned their skills from journalists who worked under heavy colonial censorship or who inherited the robust traditions of Australia or New Zealand (Cass 2001b).

98 PACIFIC JOURNALISM REVIEW 10 (2) 2004 
Different ideas about layout and design produce a great array of newspapers. Even if it were not printed in that language, its layout would be enough to mark Les Nouvelles Caledoniènnes as French. Similarly, the Post-Courier and The Fiji Times would pass as quite respectable Australian regional dailies. Circulations in the islands vary widely depending on the frequency of publication. They can be about 1000 copies for something like the Pitcairn Miscellany to 8000 for the Times of Tonga (www.tilfq.ulaval.ca/axl/pacifique/ samoa.htm). The papers may be A4 or tabloid, but, outside New Zealand, not broadsheet. The Pacific press is disparate, but it faces similar problems with costs, audiences, production and questions of political pressure.

These problems can be illustrated with reference to the non-Commonwealth states, which, although having media grounded in entirely different colonial and political experiences, share the same dilemmas. In the case of the American territories, it is a question of scale of production, with some major newspapers selling tens of thousands of copies and others with only a circulation of several hundred. In the French territories questions arise about how far the press can go in opposition to the Government and the dictates of corporate ownership.

\section{The American territories}

The former and existing American territories boast an array of newspapers. The Federated States of Micronesia has at various times had 10 papers in circulation, mostly produced by the FSM's state governments. Layton records them as having circulations of between 300 and 2500 (Layton, 1992). American Samoa supports two newspapers, an English and Samoan semiweekly called the Samoa Journal and a bilingual daily, the Samoa Daily News. Combined circulation is about 5000 (Layton, 1992). Residents of the Commonwealth of the Northern Mariana Islands have access to a variety of English and Chamorro publications, including one of the Pacific's more colourful online papers, the Marianas Variety News and Views (Layton 1992).

The largest daily circulations in the Pacific outside Fiji and PNG are in Guam, which support the Pacific Daily News, with a circulation of about 18,000 and the Guam Tribune, which sells about 22,000 copies four times a week. Elsewhere in the former and existing territories are the Palau Tribune and the Republic of the Marshall Islands Journal, which is published in English and Marshalese and sells about 3000 copies. 

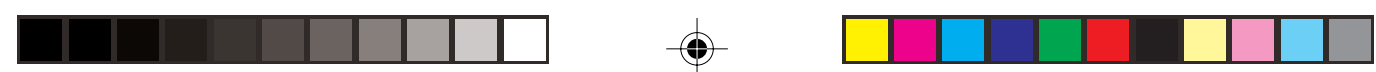

\section{MEDIA OWNERSHIP AND DEMOCRACY}

The Francophone press

The French territories in the Pacific present a unique publishing environment. Legally part of metropolitan France, New Caledonia and French Polynesia are subsidised by France, but enjoy quasi-autonomy in some areas. Nevertheless, the main newspapers, which are owned by Dassault, through its recently acquired subsidiary, Hersant, appear to be aimed at the French speakers, the pieds noir, soldiers and civil servants on short-term contracts. Such media do not serve the Kanaks in New Caledonia or the indigenous Tahitians.

The private commercial press in the French Pacific was not established in its present form until after the Second World War. The oldest newspaper in Tahiti is Les Nouvelles de Tahiti, founded in 1957 by Roger Brissaud, who also founded Les Nouvelles Caledoniènnes in 1971. Les Nouvelles de Tahiti is the oldest surviving newspaper in Tahiti. Brissaud's paper had the market to itself until 1964 when La Depêche Tahiti was first published by Philippe Mazellier and rapidly overtook Les Nouvelles in terms of circulation. Layton (1992) cited sales of 16,250 for La Depêche and 6500 for Les Nouvelles de Tahiti, while UNESCAP reported total daily newspaper sales of 24,000 in 1995 (www.unescap.org/stat/data/apif/).

La Depêche was taken over by the Hersant group's subsidiary FranceAntilles in 1988 for an estimated \$US20 million. France-Antilles took over Les Nouvelles de Tahiti in the following year and today both newspapers are printed on the same press (Robie, 1993). The only monthly in French Polynesia is the Tahiti Pacifique magazine which has been produced in Moorea since 1991 by a former journalist with Les Nouvelles de Tahiti, Alex du Prel. The magazine's 2000 copies are sold in Tahiti as well as metropolitan France.

The publishing scene in New Caledonia is somewhat different, with only one daily newspaper, but several other publications. Based in the capital Noumea, Les Nouvelles Caledoniènnes sells an estimated 13,000 copies each day. It is now owned by the Hersant subsidiary Groupe Pacifique Presse Communication. Other publications in New Caledonia include Les Quotidien Caledonien, a weekly news magazine which appears on Saturday.

Hersant's dominance of the Francophone press in the Pacific resulted from its expansion into other French overseas territories, including Martinique, Guadeloupe and French Guyana. In metropolitan France the company owns Le Figaro and several provincial dailies. The group is also said to have considered publishing an English language newspaper in Fiji after the original Fiji Sun closed in the wake of the 1987 coups (Robie, 1995: 26).

100 PACIFIC JOURNALISM REVIEW 10 (2) 2004 

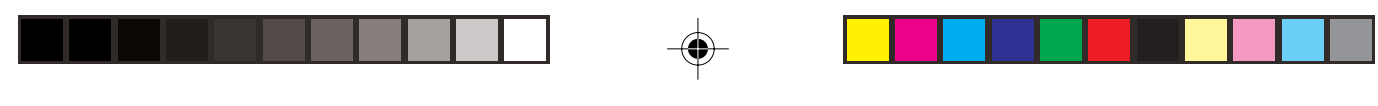

MEDIA OWNERSHIP AND DEMOCRACY

Hersant was accused of being conservative and of having an anti-independence stance. Robie has argued that journalists regarded as 'too liberal or too pro-Kanak independence' were removed when Hersant took over Les Nouvelles Caledoniènnes. Claude Marere, news editor of Radio Tefana in Tahiti, wrote: 'As part of the Hersant scenario, Polynesia must stay French, independence is taboo and silence must be kept about the corruption involved in the main political parties for the reason that they are pro-French' (Robie, 1995: 27). The acquisition of Hersant by Dassault has not been greeted warmly by French journalists. The new combination of Dassault-Hersant-Socpresse has been described as 'a menace to the press and democracy' by one syndicate of French journalists (Dassault menace la presse et la démocratie, 2004).

\section{Three major developments}

The past decade has witnessed the rise of regional magazines, the introduction of television and the development of internet news services.

\section{Magazines}

Because the daily press did not, as a general rule, tackle political or social questions in any depth, a market arose for analytical journalism and this has found its home in specialised publications such as Islands Business, Pacific Magazine and The Review. These publications filled much the same role as the 'quality' Sunday papers in other countries. In recent years, The Review has played a major part in questioning government actions and exposing corruption. During 2002, it changed its format to a quality tabloid.

Elsewhere on the magazine front, Matangi Tonga, has been distributed widely outside the kingdom to Tongans living and working overseas, particularly in New Zealand. Given the large numbers of Polynesians in New Zealand (and, to a lesser extent, in Australia) this would seem to be a market ripe for exploitation.

\section{Television}

Newspapers in most countries have always co-existed with radio, but it is only in relatively recent times that radio stations have become corporatised and therefore dependent on advertising for revenue. Television services, such as Fiji One, EmTV in Papua New Guinea and Television Blong Vanuatu, have also eaten into the advertising market. In the face of competition from 

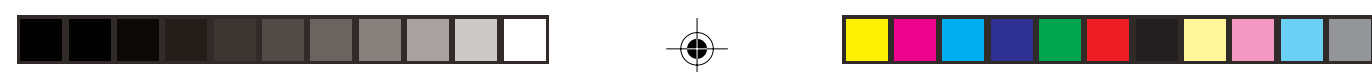

\section{MEDIA OWNERSHIP AND DEMOCRACY}

television, local media owners have had to diversify their holdings or to establish other distribution channels, most notably through the establishment of websites. However, it should be noted that television sets are bought in countries without their own television stations. This means that viewers are either watching satellite channels or, more likely, watching videos.

\section{Internet}

The Pacific media has taken to the internet with alacrity. The first regional daily news site was launched by The National (www.thenational.com.pg) in PNG in August 1996 followed by the Post-Courier (www.postcourier.com.pg) in December of the same year (Robie, 2001: 240-241). Most newspapers and magazines now have their own sites, sometimes producing them in collaboration with radio or television stations. In Fiji the two main news sites are the results of partnerships between different companies, such as fijivillage.com, a collaboration between FM96/Radio Navtarang and The Fiji Times, which now has its own website at (www.fijtimes.com), and (www.fijilive.com), a collaboration between the Daily Post and The Review magazine. Such sites often feature heavy advertising from hotels and tour companies.

While most sites appear to have been specifically designed as online news sources, others such as the Tonga Star (www.tongatapu.net.to/tonga/news/ default.htm), feature clumsily-lashed together headlines, text and scanned newspaper pages. At least one newspaper, the Islands Tribune (www.islandtribune.com) in the Federated States of Micronesia, existed at one stage solely in an electronic form. Some papers that are owned by transnational corporations provide links with their parent organisations, such as the PostCourier, which offers links to News Ltd sites through its site.

Traditionally, Pacific Islanders are a highly mobile people and communities of Tongans, Fijians, Cook Islanders and Guamanians can be found all round the Pacific rim. For those living outside their home countries, internet sites offer a link with local news and events. This is especially the case for Pacific Islanders living in Australia, New Zealand or the United States.

A number of excellent online news services provide daily coverage of Pacific news. This compensates for the general paucity of news coverage by outside organisations. Among the best are Pacific Islands Report, which originates at the University of Hawai' i in Honolulu at pidp.eastwestcentre.org/ pireport/ Other news sources for the Pacific include Pinanius at www.pinanius.org

102 PACIFIC JOURNALISM REVIEW 10 (2) 2004 
Links to major news resources in the Pacific can be found at David Robie's Café Pacific at www.asiapac.org.fj/cafepacific/ and Suzanna Layton's Coconet Wireless at uqconnect.net/ zzslayto/ Other major links to Pacific Islands media include Asia-Pacific Network at www.asiapac.org.fj, Pacific Media Watch www.pmw.c2o.org and the Pacific Islands Web Directory at www.pacificforum.com/links/Media/

The importance of the internet as a news source was demonstrated during the 1997 Sandline mercenary crisis in Papua New Guinea and the 2000 Speight putsch in Fiji when students from the University of the South Pacific's journalism course kept up a running coverage of the dramatic events online. At times their reports were the only independent source of news available (Cass, 2002).

On the whole, the Pacific Islands would appear to be well served by a diverse range of mainly locally owned media outlets. Only in New Caledonia/ Kanaky and the English market in Papua New Guinea are overseas interests dominating newspaper ownership. Foreign productions dominate television and there is no doubt that much of it is cheap junk palmed off by metropolitan vendors, but the fact remains that television is expensive to produce and until a cadre of experienced local producers, reporters, actors and technicians develop, there will be only limited local content.

\section{Conclusion}

The Pacific media are unique. While they have inherited much of the Western tradition and the Western concepts of what the role of the media should be, they have also successfully absorbed the principles of development media. As I have argued elsewhere (Cass, 1998b), the Pacific media have developed a unique, second wave of development media that is quite distinct from the classic Indian or African model, as described by Martin and Chaudhary (1983). The Pacific model derives, I would suggest, from two sources. One was the Western, democratic, liberal tradition of a free press that acted as a watchdog for its audience. The other derives from the social justice model of the media pioneered by the Catholic church in the Philippines, which in turn derives in part from the liberation theology developed in Latin America. The principles of these media have been disseminated through a number of channels, many of them ecumenical media organisations such as the World Association for Christian Communication. It has helped, of course, that much 

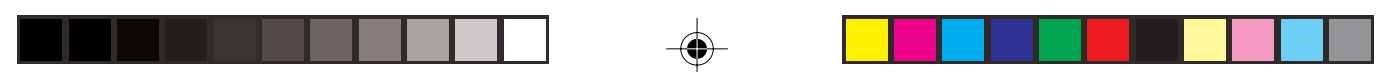

\section{MEDIA OWNERSHIP AND DEMOCRACY}

of the social justice model is compatible with secular notions about justice and national development.

The classic model of development journalism rapidly decayed into empty nationalistic rhetoric and photographs of the president-for-life receiving more East German tractors. In the Pacific, development journalism quietly seeped into the existing Western-style press and stories focused on personal and communal development, stories about literacy, education and women's rights became part of mainstream reporting.

If there is a Fa'a Pasifika, or Pacific Way, a means of finding a way to move forward and become stronger by accommodation and adaptation, then there is also Pacific journalism. It is not yet fully developed, but its outlines are distinct and, while endangered from time to time by repressive social structures and authoritarian governments, it is strong enough to survive.

For all their faults, the Pacific media have fought for change, uncovered corruption and promoted social development and they have done this through locally-owned as well as foreign owned media. Journalists are constantly urged to be agents of change in vital areas such as education and AIDS awareness (PMW 3797 HIV/AIDS, 2002). In Port Moresby, even the Murdochowned press has been quietly co-opted into the Pacific model. A Post-Courier journalist said:

News media organisations in Papua New Guinea seem to have focused on being watchdogs, reporting on what is happening. But I believe [they] have a wider role and that is to be an agent for change. Papua New Guinea is a developing country which does not have the financial resources needed for development such as health programmes etc, but established media, including radio, can be used to bring vital information to people to reinforce positive changes (Robie, 2003).

There are problems with Pacific media but they are not primarily to do with questions of ownership. The real problem for the media lies with Pacific governments and the fact that the kinds of changes being advocated (or merely presented) by the media are antithetical to traditional societies. There have been several occasions in the past decade when visiting journalists have been banned from various countries, local journalists have been pressured, threatened or beaten up, editors have been sued and governments have threatened to legislate against the media. Too many Pacific leaders have spoken approvingly

104 PACIFIC JOURNALISM REVIEW 10 (2) 2004 


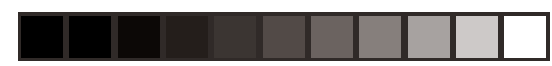

of former Malaysian Prime Minister Mahathir Mohammed's theory of the social responsibility of the press (Mahathir 1989). Too many Pacific media outlets have faced tremendous political pressure, from Taimi ' $o$ Tonga to the Vanuatu Daily Post to Fiji One (Moala, K., 2000; Moala, J., 2003; PMW 4180 Vanuatu, 2003).

Aiavao (1994) cites the example of Samoa Observer publisher Fata Sano Malifa, who has been:

sued, assaulted, received death threats, seen his printing plant and newsroom destroyed by fire in mysterious circumstances, had his paper ripped up in parliament and been accused of inciting the public.

(See also www.freemedia.at/wpfr/Australasia/samoa.htm)

Von Busch (1995) has claimed that when the Times of $P N G$ published stories about the activities of Malaysian logging firms the PNG Government sought to put Word Publishing out of business. As Crowl (1997) notes, the problem is as much cultural as political:

\begin{abstract}
Corruption, lack of leadership, poor ordering of priorities and conservatism by those in power represses initiative and speeds the vicious spiral of declining quality of life for the majority of Pacific Islanders. Politics, conservatism, fear of freedom of speech keep us from doing the best for our societies. It is long past time for us to re-evaluate priorities, to put more Government resources into education, into sharing information, into teaching people how to create knowledge.
\end{abstract}

Any media that investigate, probe and expose malfeasance in government or the upper echelons of society will face resistance. However, this is particularly the case when the entire social structure is hierarchical, regardless of whether power is exercised by hereditary chiefs or Melanesian big men. In its survey of world press freedom for 2003, the International Press Institute cites violence against journalists, political pressure, cultural pressure, banning of journalists and general restrictions upon the media as a problem in Papua New Guinea, Fiji, the Solomon Islands, Nauru, Kiribati, the Cook Islands, Tonga, Vanuatu, French Polynesia and Wallis and Futuna (www.freemedia.at/wpfr/world.html). The real challenge for the Pacific media is to use their unique combination of 

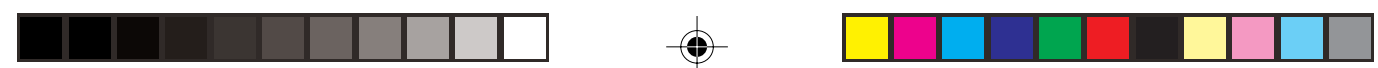

\section{MEDIA OWNERSHIP AND DEMOCRACY}

Western and development methods to the advantage of their audience, while being brave enough to challenge those aspects of islands society that need changing.

Speaking in 2003, former USP academic and deputy Prime Minister in the deposed Chaudhry Government, Dr Tupeni Baba, said:

By its very nature, [the media] is concerned with democratic values which are an integral part of liberal democracies, and Pacific countries advocating for democratic institutions which includes press and information freedom, should concentrate their efforts on enhancing the capability of the people to make their 'right' choices rather than make the assumption that they cannot make such choices and, accordingly, make choices for them (Baba, 2003: 237).

This is the central issue for the Pacific media; to weather the pressures of fearful and short-sighted governments and the restrictions of ossified social practices; and to demonstrate to governments and Western commentators that Pacific Islanders are quite capable of using the media intelligently for their own benefit. It is important to defend and continue the process by which Western, liberal, democratic standards of journalism have merged with the uniquely Pacific version of development media. 
Notes

${ }^{1}$ Any attempts at introducing media legislation or oversight in the past decade have appeared to be restrictive from one point of view or another. Media workers are incensed by moves to impose rules that mirror those of countries like Malaysia and Singapore, while academics like Baba (2003) worry that when there is voluntary oversight through such bodies as press or media councils, the views of media workers are given too much weight.

${ }^{2}$ I am indebted to Griffen (1991, passim) for information on the early Fijian press in this section. I have quoted freely from her excellent doctoral thesis on the Fijian press. ${ }^{3}$ For a colourful account of journalism in Fiji in the 1950s, see Knightley (1998).

${ }^{4}$ The producer of Shortland Street feels the programme is positively beneficial and argues that it helps open up society by presenting social dilemmas in a fictional setting (PMW 4319 Fiji, 2004). For a classic example of 'fatal impact' media anthropology, see Gouin (2001).

${ }^{5}$ As an example, publisher Kalafi Moala described oral communication and criticism as an integral of Tongan culture: 'We have a strong oral culture. Communication has always been oral and criticism is very much part of our culture. You go to a faikava (kava drinking session) and people sit round and talk. About the King, everybody!' (Moala, 1995).

\section{References}

Aiavao, U. (1994, August). The man politicians can't ignore. Islands Business Pacific. AIDAB Technical report on the National Broadcasting Commission of Papua New Guinea. (1992).

Baba, T. (2003). Reflections on the role of the Pacific media. Speech given at the Auckland University of Technology, October 3. Published as Fiji's 'embedded journalists', Pacific Journalism Review, April 2004, 10 (1): 233-238.

Cass, P. (1998a). The Pacific mission press. Pacific Journalism Review, 4(1): 105-114.

Cass, P. (1998b). I cannot photograph the adi: Self-regulation and social control in a hierarchical island society. In Allen, Holmes et al. (eds.) Self Regulation in the Media. London: City University.

Cass, P. (2000). Lotu or nation? Tok Pisin and Tok Ples as languages of identification in Papua New Guinea. Media Development.

Cass, P. (2001a). Yu mas kamap wan nesen: The role of mainstream churches in promoting Tok Pisin literacy in Papua New Guinea. Paideuma.

Cass, P. (2001b). Legal systems and the Pacific media. In D. Robie (ed.), The Pacific Journalist: A Practical Guide. Suva: University of the South Pacific.

Cass, P. (2002). Baptism of fire: How USP jourmnalism students covered the Speight coup, The Round Table: The Commonwealth Journal of International Relations, No 366, pp 559-574.

Cass, P. (2004). 'Kill Vuia': The Rabaul Times and political development on the Gazelle Peninsula 1957-59. Proceedings of Australian Media Traditions confer- 

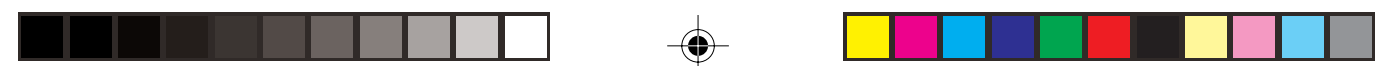

\section{MEDIA OWNERSHIP AND DEMOCRACY}

ence at www.informit.com.au/library/

Centurion, Fr Diosnel et al. (1994). National Media Policy of Papua New Guinea. Port Moresby. PNG Government.

Coleridge, N. (1998). Paper Tigers. London: Heinemann.

Crowl, L. (1996). Publishing in the Pacific Islands. Fiji Library Association Journal, 35.

Crowl, L. (1997). Local and regional book Publishing for Local and Regional Information. Paper presented at the Waigani Seminar, University of Papua New Guinea.

Dassault menace la presse et la démocratie. (2004, April 9). CFDT media release. MediasInfos. www.mediasinfos.com/archives/commun-usjcfdt07.htm

Gouin, N. (2001). Fiji Waves (film) Canada/Fiji.

Griffen, V. (1991). Control of the press and information in the British colonies 193955 with a case study of Fiji. Unpublished PhD thesis. University of Sydney.

Hughes, H. (July 2004). Can Papua New Guinea come back from the brink? Issue Analysis, 49.

Inoguchi, T. (2002). The Media and the Internet in Democratic Development. UNDP Human Development Report Office Occasional Paper.

International Press Institute. (2004). World Press Freedom Review (Australia and Oceania) www.freemedia.at/wpfr/world.html

Jamias, J. F. (1975). Readings in Development Communication. Los Banos: University of the Philippines.

Knightley, P. (1998). A Hack's Progress, London: Vintage.

Layton, S. (1992). The Contemporary Pacific Islands Press. Brisbane: University of Queensland.

Lingenfelter, R. (1967). Presses of the Pacific Islands 1817-1867. Los Angeles: The Plantin Press.

Loney, M. (2002). Pacific rural publishing: Eastern Star case study in PNG. Pacific Journalism Review, 5(1): 127-138.

Mahathir, M. (1989). The Social Responsibility of the Press. In Mehra. A (ed.). Press Systems in ASEAN State. Singapore: Asian Mass Communication Research and Information Centre.

Martin, J. and A. Chaudhary (1983). Comparative Mass Media Systems. New York: Longman.

Moale, J. (September 2003). Courageous media catalyst fuelling change behind kingdom's facade. Pacific Journalism Review, September, 9 (1): 183-186.

Moala, K. (1995). Interview. Pacific Islands Communication Journal XVI: 2.

Moala, K. (2000). Tonga and the independent press. Pacific Journalism Review, 6 (1): 59-62.

Moorehead, A. (1966). The Fatal Impact. London: Hamish Hamilton.

Nelson, H. (1967). The Press in Papua New Guinea. Paper presented at history seminar, University of PNG, Port Moresby.

News Corporation Annual Report. (1998). Controlled entities (cont). Rabaul Times Pty Ltd. p 60. www.newscorp.com/report98/financial/1998.pdf

108 PACIFIC JOURNALISM REVIEW 10 (2) 2004 


\section{MEDIA OWNERSHIP AND DEMOCRACY}

O'Reilly, Fr P., SM. (1959). Imprints of the Fiji Catholic Mission including the Loreto Press 1864-1954. Suva: The Loreto Press.

O'Reilly, Fr P., SM, and Laracy, H. (1972). Bibliographie des ouvrages publiee par les Missions Maristes des Isles Salomons. Paris: Publications de la Societe des Oceanistes.

Pacific Media Watch reports:

- (January 21, 2004). A mirror of the times. PMW 4277 PNG.,

- (February 25, 2004). TV boosts debate on social issues, says producer. PMW 4319 Fiji..

- (September 17, 2003 ). Prime Minister vows to maintain media freedom.PMW 4189 Vanuatu.

- (September 10, 2003). Media to raise concerns over Daily Post injunction. PMW 4180 Vanuatu.

- (August 20, 2003 ).Fiji Media Watch head calls for better pay, advocacy. PMW 4152 Fiji.

- (June 1, 2003 ). Fiji Times urges government to drop Media Bill. PMW 4071 Fiji.

- (March 15, 2003). Taimi 'o Tonga says government determined to ban. PMW 3982 Tonga/NZ.

- (October 15, 2002). Journalists urged to become agents of change. PMW 3797 HIV/ AIDS.

- (August 11, 2002). Anna Solomon - A remarkable journalist. PMW 3722 PNG.

Peruzzotti, E. and Smulovitz, C. (2002). Civil society, the media and internet as tools for creating accountability to poor and disadvantaged groups. UNDP Human Development Report Office Occasional Paper.

du Prel, A. (1998). Freedom of the press problems in Tahiti. Pacific Journalism Review, 5(1): 34-38.

Shawcross, W. (1992). Rupert Murdoch. Ringmaster of the Information Circus. London: Pan.

Richstad, et al. (eds.). (1973). The Pacific Islands Press. Honolulu: University of Hawai'i.

Richstad et al. (eds.). (1984). Publishing in the Pacific Islands. Honolulu: University of Hawaini.

Robie, D. (1993, October 28). Media Giants Dominate the Pacific. Times of Papua New Guinea.

Robie, D. (1995). Nius Bilong Pasifik: Mass Media of the Pacific. Port Moresby: University of PNG Press.

Robie, D. (ed.). (2001). The Pacific Journalist: A Practical Guide. Suva: University of the South Pacific.

Robie, D. (2003). Journalism Education in the South Pacific, 1975-2003: Politics, Policy and Practice. Unpublished PhD thesis. Suva: University of the South Pacific.

Stori Bilong Wantok (video). (u.d.). Port Moresby: Word Publishing.

USP Journalism Programme. (2001). Making News in the Pacific (video). Suva: University of the South Pacific.

von Busch, W. (1995, October). Book Mystery. Islands Business Pacific. 

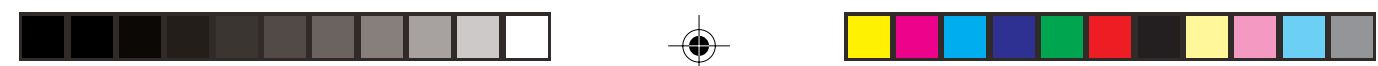

\section{MEDIA OWNERSHIP AND DEMOCRACY}

The CIA World Factbook. (2004). www.odci.gov/cia/publications/factbook

Tschauder, Fr J. (November 1992). Interview, Madang.

Windybank, S. and M. Manning. (March 2003). Papua New Guinea on the brink. Issue Analysis, No. 30.

Philip Cass is assistant dean of the College of Communication and Media Sciences in Zayed University, Abu Dhabi, in the United Arab Emirates. Born in Papua New Guinea, he has worked as a journalist, academic and journalism trainer in Australia, Fiji, PNG, UAE and the United Kingdom. He is currently researching a doctoral thesis on the islands' press and independence movements in Melanesia, 1955-75. He would be interested in hearing from people who worked in the media in Fiji, PNG, the Solomon Islands and Vanuatu during this period.

philip.cass@zu.ac.ae 